\title{
CITES, wild plants, and opportunities for crime
}

\author{
Anita Lavorgna ${ }^{1}$ (D) Catherine Rutherford ${ }^{2}$. \\ Valentina Vaglica ${ }^{3}$ - Matthew J. Smith ${ }^{4,5}$. \\ Maurizio Sajeva ${ }^{3}$
}

Published online: 11 August 2017

(C) The Author(s) 2017. This article is an open access publication

\begin{abstract}
The illegal trade in endangered plants damages both the environment and local communities by threatening and destroying numerous species and important natural resources. There is very little research which systematically addresses this issue by identifying specific opportunities for crime. This article presents the results of an interdisciplinary study which brings together criminological and conservation science expertise to identify criminal opportunities in the illegal wild plant trade and suggest strategies in order to prevent and mitigate the problem. Methodologically, the study adapts a crime proofing of legislation approach to the UN Convention on the International Trade in Endangered Species of Wild Fauna and Flora and is based on documentary and interview data. Situational crime prevention is used as a framework to provide points for effective intervention.
\end{abstract}

Keywords Cites $\cdot$ Wildlife $\cdot$ Plants $\cdot$ Crime proofing of legislation $\cdot$ Situational crime prevention

\section{Introduction}

The Convention on International Trade in Endangered Species of Wild Fauna and Flora (CITES) is the main legal framework regulating international trade in wildlife. Entering into force in 1975 , the treaty aims to ensure that international trade is not detrimental to the survival

Anita Lavorgna

a.lavorgna@soton.ac.uk

1 Department of Sociology, Social Policy and Criminology, University of Southampton, Murray

Building, 58 Salisbury Rd, Southampton SO171BJ, UK

2 London, UK

3 Dipartimento di Scienze e Tecnologie Biologiche, Chimiche e Farmaceutiche, University of Palermo, Via Archirafi 18, 90123 Palermo, Italy

4 Royal Botanic Gardens Kew, Richmond, Surrey TW9 3AE, UK

5 Microsoft Digital, Microsoft, 2 Kingdom Street, London W2 6BD, UK 
of the species in the wild. Any such trade should be sustainable, based on sound biological criteria, and legal, according to appropriate and rigorous national legislation. However, endangered species are also traded illegally, in contravention of CITES and its guiding principles.

Wildlife trafficking has only been given attention in criminological studies recently, despite being the concern of conservation science for decades (Sajeva and Carimi 1994; Dobson 1996; Regan 2004). It has been recognised that a socio-legal understanding of the illegal exploitation and destruction of natural resources is critical to successful prevention, detection and control (Herbig and Joubert 2006; Gibbs et al. 2010). Considerable progress has been made in using multidisciplinary approaches that integrate diverse expertise to better address the complex challenge of preserving natural resources (Alacs et al. 2010; Gibbs et al. 2010; Lemieux 2015; Moreto 2016).

This study furthers this path of inquiry by using criminological approaches - those of crime proofing of legislation (hereafter CPL) and situational crime prevention (hereafter SCP) - to propose ways to overcome some of the challenges encountered by conservation scientists and law enforcement officers in dealing with the illegal trade in wildlife. Specifically, the study relies on CPL to identify criminogenic opportunities in the existing framework regulating trade in wildlife and suggests points for intervention through a SCP approach. Given the heterogeneity of the criminal markets in wildlife and the necessity to be crime specific in identifying and tackling criminal opportunities (Clarke 2012), the analysis and discussion will focus uniquely on wild plant trafficking. After providing a brief history of international trade in wild plants and how it is regulated under CITES, the article will present the data collection and the analytical approaches used, and systematically identify criminogenic aspects in the CITES regulatory framework. Finally, potential interventions to mitigate the problem will be presented and discussed.

\section{Background}

\section{A brief history of wild plant trafficking}

While the illegal trade in wild animals (and animal parts, e.g. ivory) is receiving increasing attention by both criminologists and the general public, the illegal trade in plants has so far been relatively overlooked (with some notable exceptions, such as van Solinge 2008; Wyatt 2013, 2014). Wild plant trafficking threatens and destroys numerous species and important natural resources (Herbig and Joubert 2006; Phelps and Webb 2015), and it hinders the rule of law, security and good governance (UNODC 2016; Haenlein and Smith 2017).

Trade in wild plants increased in America and Europe after the Second World War. As a result of increased disposable income, greenhouses and heating became more affordable leading to an increase in demand for exotic plants (Sajeva and Carimi 1994; Sajeva et al. 2007). Unfortunately, the profitability of the market also boosted the trade of endangered species: the demand for wild plants intensified the pressure on wild populations, and some taxa (i.e. any taxonomic category, as a species or genus) such as rare species of Ariocarpus (a genus of Mexican cacti) became virtually extinct in the wild by the end of the 1970s (Sajeva et al. 2007). This pressure on wild populations still applies to cacti and to several other plant groups for the horticultural trade, such as orchids, cycads and carnivorous plants (Phelps and Webb 2015; Olmos-Lau and Mandujano 2016; RBG Kew 2016, 2017; Vaglica et al. 2017). The illegal trade of wild plants is also increasingly affecting timber species traded for their desirable 
aesthetic and construction qualities, which led to the inclusion in CITES Appendix II of several taxa - such as Dalbergia, a genus of rosewood (CoP 17 2016). Furthermore, wild plants are illegally traded for their medical or alleged healing properties, such as a number of aromatic plant species.

Trade over the Internet over the past two decades has led to an escalation of the problem: it accelerated the illegal plant trade and made it a real "hybrid" (online and offline) market (Lavorgna 2014). In fact, no matter how highly specialised the market in certain wild plants is, it is much easier to find potential buyers or sellers online than in the physical world (Wu 2007; Interpol 2013; Sajeva et al. 2013; Lavorgna 2014; Olmos-Lau and Mandujano 2016).

\section{The regulatory framework}

As noted in the Introduction, the main legal framework regulating wildlife trade is the 1975 Convention on International Trade in Endangered Species of Wild Fauna and Flora (CITES). ${ }^{1}$ As of early 2017, 183 countries have ratified the Convention. CITES aims to control the trade of species in which international commercialisation and over-exploitation is a serious threat to their survival, or could threaten survival in future if not regulated. Therefore, as clarified in its Preamble, the main scope of the Convention is to protect biodiversity and the intrinsic cultural, aesthetic and economic value of wild fauna and flora (Young 2003).

CITES provides three levels of protection for endangered species, depending on their level of threat ${ }^{2}$ : species listed on Appendix I are threatened with extinction and their trade in wild specimens is permitted only in exceptional circumstances. Species included in Appendix II are considered vulnerable and their international trade is strictly regulated; trade in wild collected specimens is allowed but is subject to the issuance of a permit. This Appendix also includes "look-alike" species that are difficult to differentiate from those threatened, although they themselves might not be at risk of extinction. Species listed in Appendix III are protected in at least one country, which has asked other CITES parties for assistance in controlling the trade; trade in wild collected specimens is permitted but is subject to export permits or certificates of origin. Each Party to the Convention must designate one or more Management Authorities in charge of administering the licencing system and one or more Scientific Authorities to advise them on the effects of trade on the status of the species. Public and media attention are focussed on charismatic fauna, but the number of threatened plants is far higher: more than 30,000 taxa of plants are included in the CITES Appendices, but only about 5000 taxa of animals.

One of the consequences of CITES has been to encourage "artificial propagation" of many plants. The increase in the availability and variety of plants grown in controlled conditions improved access to supplies of cheap, high quality, uniform and disease-free plants while taking the pressure off wild populations (Sajeva et al. 2007). However, some plant collectors still prefer wild collected plants because they have a "history" and better display the aspect they have in their original habitat (Sajeva et al. 2012; RBG Kew 2017). Furthermore, some buyers in the medicinal plant market can show preference for wild collected plants, claiming they contain superior active ingredients (McGough et al. 2004; Sajeva et al. 2012).

\footnotetext{
${ }^{1}$ In the EU, CITES has been implemented by Council Regulation N. 338/1997 and Commission Regulation 865/ 2006. The EU Wildlife Trade Regulations, directly applicable in all Member States, go beyond the provisions of CITES to impose stricter control over wildlife trade (Engler and Parry-Jones 2007).

${ }^{2}$ See https://www.cites.org/eng/app/index.php and https://www.cites.org/eng/app/appendices.php for further details.
} 
While CITES has been praised overall as a good mechanism to ensure the sustainable use of natural resources (Zimmerman 2003; Warchol 2004; Rivalan et al. 2007; Wyatt 2016), it has also been subject to a number of criticisms. Firstly, the regulation and control of wildlife trade depends on different national environmental policies and ethical value judgments, resulting in a lack of harmonisation of national legislation and creating loopholes for criminal exploitation (Sand 1997; Young 2003; Lemieux and Clarke 2009; Bowman 2013; Sollund 2015; Sollund and Maher 2015; Maher and Sollund 2016); in particular, CITES' approach of "(black)listing” species has been criticised as an inherent weakness and a legacy of poor historical understandings of the complexities of biodiversity (Couzens 2013). Secondly, as stated by Sand (1997: 55) 20 years ago, CITES may have "reached its outer limits", as the relevance of CITES-type border controls decreases with the abolition of internal trade borders in "new" realities such as the European Union. Thirdly, there are problems concerning the enforcement of CITES, which is not a self-executing treaty (Zimmerman 2003; Izzo 2010; Sand 2013). ${ }^{3}$ Finally, according to the critical stand of Sollund (2011), the legal structure provided by CITES could even legitimise wildlife trafficking, as it regulates the trade of already endangered animals and plants rather than banning it tout court. It could be argued that this is not the case, given that international trade in endangered species (listed on Appendix I) is banned under CITES except for exceptional circumstances, whereas it is allowed (under permit) for Appendix II species, which are not yet endangered but could become so if trade is not regulated. The criticisms, however, mainly originate from the observation of unintended consequences in country-specific case studies; academic research has not yet systematically analysed the legal framework in order to specifically flag potentially criminogenic provisions.

\section{Crime proofing of legislation and situational crime prevention}

Criminological research has already shown that the regulations, and their implementation, governing legitimate markets might be criminogenic, creating unintended criminal opportunities (Albrecht and Kilching 2002; Russell and Clarke 2006; Transcrime 2006; Dorn et al. 2007). CPL was developed as an approach to assess existing or future opportunities for crime due to legislation and indicate potential interventions aimed at proofing it against crime. It proved to be a valid form of risk assessment and management, and it served in the past to provide a comprehensive scan for criminal opportunities arising from regulations and their implementation (Russell and Clarke 2006; Transcrime 2006). The model developed by Transcrime (2006), for instance, was created to assess the risk of unintended consequences produced by legislative measures, and to suggest textual changes to the legislation in order to reduce opportunities for crime. Nevertheless, despite the evidence of the existence of a major criminal problem, this approach has never been used to understand in a

\footnotetext{
${ }^{3}$ However, as a mechanism of sanctions against defaulting states, there is the possibility to "ban" a state if not complying with CITES regulations by suspending commercial trade of all CITES listed species. This happened to Italy in the 1990s: at that time Italy was a Party to CITES but had not implemented national legislation. The ban stopped all import-export of CITES listed taxa and the fashion industry was among the strongest lobbies that pushed the government to produce a sound legislation. More recently, trade sanctions were imposed on Guinea Bissau and Liberia (https://cites.org/sites/default/files/notif/E-Notif-2016-030.pdf).
} 
systematic way whether and how the norms regulating wildlife trades could have an unintended criminogenic role, or whether there are major loopholes in their implementation that are currently exploited.

Overall, criminological studies on the CPL belong to the wider group of crime opportunity approaches, which share the idea that opportunity is a root cause of crime (Felson and Clarke 1998) and aim to reduce crimes by looking for crime patterns in specific environments (Clarke 2009: 262). The focus is thus on the situation in which crime occurs: if behaviour is seen in a dynamic relationship with the environment, the propensity to commit crime depends upon immediate circumstances, which have an active role in "readying" the (potential) criminal to act (Wortley 1997: 74). In other words, all these approaches build on the statement that "opportunity makes the thief" (Felson and Clarke 1998: v). The study of opportunity structures has already proved beneficial in research on wildlife crimes (Wellsmith 2010; Moreto and Clarke 2013; Lavorgna 2014; Lemieux 2014) but to the authors' knowledge it has never been used specifically to study CITES and wild plant crime.

Opportunity approaches are at the basis of SCP, a practical approach to crime prevention that seeks generally to alter the immediate causes of crime by modifying the decisions that precede the commission of a crime through five main opportunityreducing techniques: increasing the offender's perceived effort, increase the risk, reduce the rewards, reduce provocations and remove the excuses (Clarke 1992; Cornish and Clarke 2003). More recently, Freilich and Newman (2014) expanded the situational crime prevention approach by suggesting a sixth technique, i.e. to provide opportunities to manipulate behaviours. In this way, a total of 30 situational crime prevention mechanisms can now be identified (summarised in Appendix).

As already suggested in the literature, framing CPL within the SCP approach means it is not only possible to identify unintended criminal implications in existing legislation, but also to develop suggestions on how to mitigate it (Savona 2017): once we have identified specific criminogenic opportunities through CPL, we can use SCP as a reasoning tool to propose potential solutions. This study will 1) apply the CPL approach on the CITES regulatory framework to identify criminogenic aspects regarding the illegal trade in endangered plants, and 2) identify and discuss potential SCP measures to prevent and/or mitigate such illegal trade.

\section{Methodology}

Our methodology has two complementary parts. First, CPL (based on document analysis and email interviews with CITES representatives in 13 countries) was applied to CITES to identify crime opportunities. Second, SCP was used as a framework to identify priorities to be addressed by the CITES community to prevent and mitigate the illegal trade in endangered plants.

The CPL model adopted was developed by Transcrime (2006), with adaptations. The socalled MARC model (Transcrime 2006) was conceived to enable policy makers to evaluate legislation in the law-making process and to suggest changes (e.g. textual changes) to reduce the crime risk. Our revised model is used instead by multidisciplinary researchers (from criminology and plant ecology) and practitioners from environment authorities to identify criminogenic opportunities in the legislation and its implementation on the basis of textual aspects of the text, document analysis, expert interviewees and case studies. 
According to the MARC model, CPL is useful when a piece of legislation follows within certain risky indicators (initial screening). ${ }^{4}$ CITES increases the cost of legal goods (because of its system of export permits), regulates/restricts the trade in demanded products, and provides officials with regulatory powers - hence, it meets risky indicators no. 4, 5 and 7 (see footnote 4). At this point, the MARC model would proceed according to a specific sequence of steps. ${ }^{5}$ In our revised model, however, given that the aim was to identify specific criminal opportunities to apply SCP rather than to produce recommendations for policy makers and regulators, we merged and adapted the preliminary and extended crime risks assessments to develop a framework to guide and systematise our identification of criminogenic elements in CITES and its implementation. In particular, we used the Legislative Crime Threat element, which looks at specific textual deficiencies and market vulnerabilities. In order to assess the textual deficiencies, the following indicators need to be considered: external consistency (i.e. the impact of the legal act on the existing legislative framework); internal consistency (the internal organisation of the legal act); clarity of content (the language used); enforceability (implementation mechanisms). In order to assess the market vulnerabilities, the following indicators need to be considered: attractiveness (which depends on profitability and the risk of detection) and accessibility (i.e. the capacity of criminals to infiltrate a given market) (Transcrime 2006: 17ff). For cases of trafficking of goods - also, therefore, for trafficking in wildlife — profitability depends on the introduction of duties on legal goods, and restrictions to the production and distribution of goods. Risk of detection depends on the transparency of the market (i.e. how much easier it is to identify smugglers), the presence of discretionary powers of guardians and officials, and their professionalism and experience. Finally, accessibility depends on the requirements for market entry and the presence of background checks.

Guided by the indicators suggested in the MARC model (see Transcrime 2006 for further details) and inspired by the analysis carried out by Morgan and Clarke (2006) to identify risky indicators for new legislative proposals, we systematically analysed CITES documents to make explicit the relationship between specific CITES provisions and criminogenic mechanisms leading to unintended consequences.

The data presented in the Findings were gathered through a two-step process. Firstly, data on textual problems and related case studies were retrieved from official CITES documents (e.g. working and information documents from the Conferences of the Parties, documents from the meetings of the Plant Committee and the Standing Committee), which are available through the CITES website. ${ }^{6}$ Documents were taken into consideration from the most recent backwards, such that relevant and recent

\footnotetext{
${ }^{4}$ The indicators are: 1) Legislation that induces product disposal regulations or any other new or burdensome fee or obligation; 2) Legislation that introduces a concession on a tax or a concession on any other fee or obligation; 3) Legislation that introduces grant, subsidy or compensation scheme or any other scheme that provides a benefit; 4) Legislation that introduces or increases the tax on legal goods or in any other way increases the cost of legal goods; 5) Legislation that prohibits or restricts a demanded product or service or in any other way decreases the availability of demanded goods or services; 6) Legislation that introduces or removes a law enforcement capacity, increases or decreases funding for enforcement activity or in any other way impacts the intensity of law enforcement activity; 7) Legislation that provides officials with regulatory powers (Transcrime 2006: 3).

${ }^{5}$ Preliminary crime risk assessment (a descriptive activity where the formal aspects of legislation are roughly assessed, and the vulnerability of the market and the crime risks are estimated to draw broad conclusions in terms of crime risks); extended crime risk assessment (a quantitative assessment of unintended criminal implications to calculate the Legislative Crime Risk Index, which is the result of the Legislative Crime Threat Index and the Seriousness Index); conclusions and recommendations.

${ }^{6}$ https://www.cites.org/
} 
unintended consequences and examples were found. These data were integrated with critiques to the CITES text in known previous academic literature and other documentary sources (e.g. official reports and recommendations from NGOs). This initial scan allowed us to have a first overview of the CITES weaknesses as already identified in existing documentary sources. Thematic coding was carried out manually.

Secondly, we carried out structured interviews with representatives of CITES Management and/or Scientific Authorities of 13 countries. The researchers contacted via email potential respondents from a total of 76 countries: specifically, the 28 Members States of the European Union, the remaining 21 states of the European Region as main importer countries of wild plants, and an additional 27 states, distributed in all the other continents, that are major traders and countries of origin of the two exotic taxa of plants mostly traded into Western markets (cacti and orchids). The sampling was partially limited by pre-existing contacts between the selected countries and members of the research team, which facilitated the email exchange; further research could expand our study to other countries. Respondents from the following 13 countries participated in the study: Australia, Austria, Estonia, Finland, Honduras, Italy, Madagascar, Mauritius, Mexico, Myanmar, Namibia, Turkey and Vietnam (for a total of 17 respondents; more than one person replied in some countries). Email interviewing (carried out in March 2017) allowed the researchers to include geographically dispersed respondents, who would have been otherwise difficult to access (McCoyd and Kerson 2006; O’Connor and Madge 2017). We asked our respondents open-ended questions focusing on whether they encountered specific problems in CITES framing and implementation in the course of their duties, and on potential solutions and best practices. We asked our respondents to provide specific examples whenever possible. As before, the answers were thematically analysed through manual coding. The respondents have been anonymised in the Findings.

\section{Findings}

\section{Criminogenic opportunities: results}

This section presents the results of our analyses of CITES documents and CITES implementation. It identifies criminogenic opportunities by pointing out specific CITES provisions and loopholes that give rise to unintended consequences, and the vulnerability indicator as presented in the MARC model (Transcrime 2006, see above). Specific examples are provided whenever available.

CITES provision \& risky element: Preamble. It equates "aesthetic, scientific, cultural, recreational and economic" reasons for $\overline{\text { defending }}$ wildlife.

Intended consequences: Allows flexibility in the Parties' interpretation of which method is preferable to achieve wildlife protection.

Unintended consequences and mechanism: Can create confusion, as the text allows for both preservationist and conservationist interpretations (Young 2003). Preservationism is the idea that nature has an intrinsic value and that humans should make as little changes as possible to it. Conservationism is the idea that natural resources have an instrumental value and should be wisely managed by humans to maximise the benefits they can offer.

Indicator: clarity of content. 
CITES provision \& risky element: Art.1 (Definitions) Defines "species" as "any species, subspecies, or geographically separate population thereof" (art.1a).

Intended consequences: Enables a country to protect its own wildlife from potential extinction in that country, regardless of the species' abundance elsewhere.

Unintended consequences and mechanism: (1) Can create confusion, as a certain species might be abundant in one country and endangered in another (Meyers and Seligsohn Bennet 1989; Young 2003); (2) Problems encountered with the discovery and identification of new species. For instance, recently newly described taxa of Mexican cacti were found online within months of their discovery, with increasing numbers of collectors looking for the newest species (European Regional CITES Plants Meeting 2014).

Indicator: clarity of content; attractiveness; accessibility.

CITES provision \& risky element: Art.1 (Definitions) Specimens and their derivatives have to be "readily recognisable" (art.1b).

Intended consequences: Facilitates management in the CITES implementation.

Unintended consequences and mechanism: (1) Creates a loophole, as "readily recognisable" is not well defined (Meyers and Seligsohn Bennet 1989; Gillespie 2011). The identification of exotic timber and derivatives (figures, musical instruments etc.) is particularly complicated (e.g. Buddha figures from Thailand and Cambodia) (Respondent B); (2) New problems arise as companies and individuals are producing "bioengineered" products which look, feel and taste as real wildlife products (CoP17 Inf.22); (3) When plants and their derivatives are used as medicines, supplements and cosmetics, they are sometimes traded without CITES paperwork (many of these incidents appear to be the result of ignorance or negligence, not criminal intent) (UNODC 2016). For instance, cases of orchid derivatives (Meeting of the Enforcement Group 2015; RBG Kew 2016); aloe, cacti, sandalwood etc. (European Regional CITES Plants Meeting 2014; Respondents B, E).

Indicator: clarity of content; external consistency; enforceability; accessibility.

CITES provision \& risky element: Arts. 3, 4 \& 5 (Regulation [...] Appendixes I, II \& III) No advice of Scientific Authority is needed for re-export certificate (art. 3(4) \& art.4(5)).

Intended consequences: Allow the commercial sustainable use of species even if listed in the Appendixes.

Unintended consequences and mechanism: Annotations to listed species (annotation $4(\mathrm{~b})^{7}$ calls for "seedling or tissue cultures [...] transported in sterile containers"). However, after the plant is removed from the container, it is difficult to determine the artificially propagated origin because of lack of documentation. This occurs when more than one authority is involved (e.g. in the EU) (Respondent A). For instance, orchids might arrive to one country in a sterile container. After they are removed from the container, they are transported elsewhere and sold. At this point, there is no longer CITES documentation and it is impossible to prove an illegal import (Respondent A).

Indicator: enforceability; attractiveness.

CITES provision \& risky element: Arts. 3, 4 \& 5 (Regulation [...] Appendixes I, II \& III). "A Management Authority of the State of export is satisfied that the specimen was not obtained in contravention of the laws of that State for the protection of fauna and flora" (art. $3(2 b), 4(2 b) \& 5(2 a))$.

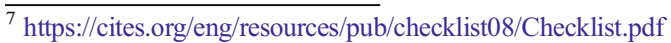


Intended consequences: Ensure trade is legally sourced in accordance with national legislation. CITES provides a framework respected by each Party, which must adopt their own domestic legislation to implement CITES at the national level.

Unintended consequences and mechanism: (1) The Convention does not provide guidance on how to make a so-called Legal Acquisition Finding (certifying that the specimen was not obtained in contravention of national legislation). It is the obligation of an applicant for an export permit to provide information that will satisfy the Management Authority that the relevant specimens were legally acquired. The Convention places considerable responsibility upon the CITES Management Authorities of the State of export to ensure that specimens of listed species entering international trade are of legal origin and exported at sustainable levels. ${ }^{8}$ Unfortunately, when a recommendation is made to suspend trade in a specific species from one country, there may be increased legal and illegal exports of the species from neighbouring or third countries. In the case of illegal trade, this increase could be an indication of well organised transnational smuggling combined with a failure to properly determine legal acquisition. If such failures become systematic, they provide unscrupulous traders with the opportunity to "launder" illegally-obtained specimens (plants and animals) into the international market under the cover of genuine CITES permits through neighbouring countries. (CoP17 Doc. 23) ; (2) Can create random exemptions. For instance, "regarding Madagascar's implementation of CITES listings for plant species, the [Plants] Committee requested that the Secretariat seek clarification from Madagascar concerning a policy which apparently allows tourists to export (up to) five specimens of CITES-listed plants without CITES permits or certificates" (CoP17 Doc 10.3.1); (3) No common standards are provided. Annotations can be very different among countries (Respondent K). The interpretation of annotations varies considerably between Parties, and the lack of a common understanding creates considerable challenges in implementing the Convention, particularly for plants.

Indicator: internal consistency; clarity of content.

CITES provision \& risky element: Art.4 The Scientific Authority "shall advise" the Management Authority of "suitable measures to be taken to limit the grant of export limits" (art.4(3)).

Intended consequences: Ensures that endangered species are subject to a stricter system of controls.

Unintended consequences and mechanism: (1) In the implementation stage, often a management plan is requested for each species. However, in many countries there are no funds for these studies and this can become very critical in countries with high numbers of listed species, such as Madagascar (Respondent E); (2) NDFs ${ }^{10}$ (Non Detriment Findings are poorly

\footnotetext{
${ }^{8}$ Regarding the designation and role of the Scientific Authorities, Resolution Conf. 10.3 (CoP 10, https://www.cites.org/eng/res/10/10-03C15.php) recommends that "all Parties designate Scientific Authorities independent from Management Authorities" (art. 3(2a) Res Conf. 10.3) in order to prevent corruption and to foster independent scientific advice. Unfortunately, this is not always the case (e.g. in some countries both the Scientific and the Management Authorities are part of the Ministry of the Environment (see https:/cites. org/eng/cms/index.php/component/cp).

9 This is relevant also to Art.8.

${ }^{10}$ The preamble to the Convention recognises that the protection of certain species of wild flora against overexploitation through international trade is essential. However, the point at which such over-exploitation starts has never been defined by the Parties. Terms used in the text of the Convention such as "threatened with extinction" and "utilisation incompatible with their survival" (art.2) in relation to inclusion of species in the Appendices have been defined through the adoption of Resolution Conf. 9.24 (Rev. CoP16) on Criteria for amendment of Appendices I and II. However, related concepts linked with the issuance of permits (art.3 and 4) have been little clarified by the Parties. These have become collectively known as the "non-detriment findings" (NDFs).
} 
managed, there is lack of information to formulate them properly). Also, most NDFs are done after the harvest, while they should be made before (Respondent G).

Indicator: enforceability.

CITES provision \& risky element: Art.6 (Permits and certificates). Any copies of a permit or certificate issued by a Management Authority shall be clearly marked as copies only and no such copy may be used in place of the original, except to the extent endorsed thereon (art.6(4)). Management Authorities have to affix a "mark" on specimen to assist in their identification. The "mark" has to be "designed in such a way as to render its imitation by unauthorised persons as difficult as possible" (art.6(7)). ${ }^{11}$

Intended consequences: A licencing system is in place for all import, export, re-export and introduction from the sea of species covered by the CITES.

Unintended consequences and mechanism: (1) The article does not provide provisions to share information on permits and certificate among the Parties ${ }^{12}$; (2) The Scientific Authority might have to establish plant ID techniques of high numbers of species. While technically feasible, this can be a challenge for the lack of funding and international cooperation. E.g., cases of wood ID techniques for Dalbergia and Diospyros (Respondent E); cases regarding timber (Respondent $\mathrm{G}$ ). Moreover, this requirement does not align well with electronic, risk based border clearance processes - and there is a move towards e-permitting (CoP17 Doc. 44 (Rev. 1)); (3) Paperwork can be forged (Respondent J). E.g, over 100 cases where Siamese rosewood was seized in Thailand over the years due to misdeclaration of species (UNODC 2016); (4) There is no regulation on how to treat individual specimen imported under a certain purpose code, ${ }^{13}$ in particular if there is a change of purpose in case of re-export (Respondent A). E.g., shipments of artificially propagated specimens have been imported legally from Peru under phytosanitary rules, however closer inspection has revealed the specimens were wildcollected (Meeting of the Enforcement Group 2013). E.g., someone from a third country imported a plant under the code "scientific" and then exported artificially propagated plants as "commercial" to the EU. The case does not seem to be isolated and this modus operandi is likely to affect highly endangered species (Respondent A). In a hypothetical example, a high value orchid species like Paphiopedilum rothschildianum might be imported with all necessary documentation. The same documentation might be used to legalise illegal individuals of the same species (Respondent A). Also, reported cases of orchids and succulent species (Respondent E); (5) Due to the nature of plants, there is no tradition of keeping track of individual plants (as it occurs in the case of animals). Therefore, it is relatively easy to use the same documents for different plants (Respondent A); (6) Airlines often do not require the mandatory documentation, which facilitates illegal importers (Respondent D); (7) Traders can withhold information, e.g. on location and nomenclature (Respondent E); (8) Entirely avoiding control

\footnotetext{
${ }^{11}$ In order to prevent fraudulent permits, Resolution Conf. 12.3 (Rev. CoP16), paragraph XIV f) recommends that: "Export permits and re-export certificates be endorsed, with quantity, signature and stamp, by an inspecting official, such as Customs.

${ }^{12}$ However, the United Nations Environment Programme's World Conservation Monitoring Centre (UNEPWCMC) is developing a mechanism to facilitate the electronic exchange or verification of CITES-Permit data among Management Authorities. The tool, known as EPIX (Electronic Permit Information eXchange), is being developed so that participating Management Authorities can exchange data regardless of the type of informationmanagement system used by each Authority. This mechanism is being developed in communication with the CITES e-permitting working group which is developing standards for data electronic exchange (see https://cites. org/eng/prog/e/e-permitting-toolkit.php).

${ }^{13}$ That is, a letter used on CITES permits and certificates to indicate the purpose of trade in the specimen covered therein (e.g. commercial, botanic garden, etc.).
} 
by sending plants in shipments where they will not be found (no permits involved). E.g., in Guatemala, illegal trade in rosewood logs were found to be hidden in shipments recorded to be exporting recycling material (such as cardboard, junk or scrap metal) or other non-protected timber species (Vaglica 2016).

Indicator: external consistency; internal consistency; enforceability; accessibility.

CITES provision \& risky element: Art.7 (Exemptions) Exemptions for: personal or household effect; for artificially-propagated specimens or their derivatives; for specimens taken from the wild before they become listed; donation or exchange between scientific institutions or plant exhibitions (Art.7(2-6)).

Intended consequences: In order to facilitate the cross-border movement of endangered species under specific circumstances, if one of these exceptions applies, no permits or certificate are needed.

Unintended consequences and mechanism: (1) Possible fraudulent claim of one of these exceptions. At times, it is very complicated to determine whether the exemption applies (especially for certain species); certificates (e.g. of artificial propagation) can be forged (Young 2003; Respondent A). Consider, for instance: "We do have commonly artificially propagated species in trade that are highly endangered in the wild. There are reliable provisions for orchids, but in the case of cacti there is no reliable trade form like orchids in a flask. If someone manages to smuggle an Astrophytum asterias from the wild to Thailand, I will not find it ever again" (Respondent A); (2) There are increasing numbers of plants from legacies of deceased collectors on the market. It is very difficult to verify their origin/legality at all (Respondent A).

Indicator: clarity of content; accessibility.

CITES provision \& risky element: Art.8 (Measures to be taken by the Parties) The Parties shall take "appropriate measures" to enforce the Convention, which include "to penalize trade in, or possession of" prohibit specimens (Art.8(1a)). The Parties shall maintain records of trade in specimen $[\ldots .$.$] (Art.8(6)).$

Intended consequences: CITES provides a framework respected by each Party, which must adopt their own domestic legislation to implement CITES at the national level.

Unintended consequences and mechanism: (1) CITES does not require these violations to be deemed a crime (e.g. they might be punished with a fine) and there is no threshold for penalisation (UNODC 2016); (2) The effectiveness of the treaty depends on whether the Parties implement relevant provisions within their borders. Enforcement has often proved to be ineffective. Developing countries might willingly not enforce. E.g., TRAFFIC experiment (Cacti listed in CITES Appendices were transported across 10 countries; only the US and exUSSR confiscated the cacti, but for health issues and not because of CITES) (Meyers and Seligsohn Bennet 1989; Young 2003); (3) Potentially illegally sourced plants might enter the legal supply chain before export, and then be freely traded internationally (the "laundering" can take place before CITES applies). E.g., as CITES controls were placed on rosewood, traders began to rapidly extract those species that were not listed. Source countries tried to put their own controls in place, but without CITES, most countries cannot legally reject a shipment of rosewood simply because it was illegally harvested or exported, as they lack in their domestic law instruments for acknowledging the wildlife regulations of other countries (UNODC 2016); (4) Some parties lack adequate resources/training for effective enforcement (Young 2003; Respondent E). E.g., in the case of agarwood the product can assume forms of which law enforcement is unaware (UNODC 2016); (5) Increasing problems with Internetfacilitated trade where species can be traded bypassing controls, small-scale postal shipments 
and small-scale illegal trade concealed in travellers' luggage. E.g., operation "Attila" concerning live plants from Chile to Italy confiscated in airports and postal shipments (Respondent K); Mexican cacti found online within months of their discovery (European Regional CITES Plants Meeting 2014); (6) Difficulties in reporting all trade in artificially propagated plants, especially if there are not proper schemes to register nurseries (European Regional CITES Plants Meeting 2014). E.g., cases for orchids and succulents (Respondent E).

Indicator: external consistency; enforceability; accessibility.

CITES provision \& risky element: Art.11 (Conference of the Parties) \& art.15 (Amendments to Appendices I and II) "The Secretariat shall convene regular meetings at least once every two years" for the Parties to "consider and adopt amendments to Appendices I and II in accordance with Article 15".

Intended consequences: A timeframe for meetings is provided.

Unintended consequences and mechanism: This is the only time the Appendices can be amended (other than the rarely used postal vote/exceptional meeting) and if an annotation needs changing or a new species listed, it is sometimes too late (e.g. for Dalbergia cochinchinensis) (EIA 2016). In addition, Conferences of the Parties (CoPs) often occur every 3 years rather than every two, which could provide an even longer time window that may exacerbate known problems.

Indicator: attractiveness.

CITES provision \& risky element: Arts.15(3); 16(2); 23. Reservations.

Intended consequences: A reservation is a unilateral statement by a Party to not be bound by the CITES provisions for a species listing. This introduces an element of flexibility and can promote international cooperation.

Unintended consequences and mechanism: An export permit is required if the Party with a reservation exports to a Party that has not taken out a reservation on the same species (RBG Kew 2016). E.g., Reported cases of Japan and ex-URSS countries importing endangered wildlife (Young 2003); E.g., Hong Kong has not implemented CoP16 timber listings in the legislation and has become a black hole for laundering Malagasy palisander and rosewood (European Regional CITES Plants Meeting 2014).

Indicator: External consistency; accessibility.

CITES provision \& risky element: Art.18 (Resolution of disputes).

Intended consequences: In order to preserve state sovereignty, a system of central cooperation is not imposed.

Unintended consequences and mechanism: Enforcement problems due to the lack of any central enforcement entity. Party compliance relies on persuasive means (Young 2003).

Indicator: Enforceability.

\section{Criminogenic opportunities: discussion}

The previous section provided a systematic overview of current vulnerabilities in CITES and its implementation. It showed how a regulation, and its implementation, governing a legitimate market can have vulnerabilities and consequently create unintended criminal opportunities, consistent with previous research (Morgan and Clarke 2006; Transcrime 2006). Our results suggest that CPL remains a valid tool to assist the assessment of regulatory frameworks, and proves to be useful well beyond criminological and legal studies (in our case, conservation science) to guide an expert-led identification of unintended criminogenic factors. 
It is worth noting that three respondents $(\mathrm{D}, \mathrm{G}$, and $\mathrm{H})$ denied the existence of specific problems with CITES (which is "pretty straightforward in its provision", Respondent G), even if two of them (D and G) identified specific problems in its implementation. In addition, Respondent $\mathrm{C}$ replied that his/her country did not have seizures of illegal plants or knowledge of trafficking routes, nor in fact much legal trade in CITES plants either. However, considering recent research on CITES noncompliance and on dark numbers in the trade of endangered plants (Vézina 2015; Hinsley et al. 2016; Olmos-Lau and Mandujano 2016), illegal aspects of the trade might simply be occurring under the radar of law enforcement in certain countries. More research to estimate the dark numbers of wild plant trafficking is certainly needed.

While the previous section followed the order of CITES provisions to identify existing problems, some of the criminogenic opportunities are recurrent and can be best summarised in the following list:

ambiguity in the terminology and definitions used;

time gap between the discovery of new species (potentially endangered) and their listings in the Appendices;

difficulties in recognising derivative products;

loopholes in the paper trail of plants and derivatives in cases of re-export;

lack of financial/scientific/legal/administrative resources in certain countries;

lack of monitoring and enforcement of Internet-facilitated trades;

documents can be easily forged and information easily withheld or presented in a misleading way by importers and/or traders;

difficulties in cross-border relationships.

Overall, all the indicators developed in the MARC model in the Legislative Crime Threat element were identified in CITES, with a prevalence of external consistency, clarity of content, enforceability and accessibility problems. It is therefore on these aspects that the SCP analysis will focus.

Opportunities that are inherently linked to CITES raison d'etre, such as the fact that the Convention itself does not provide for enforcement mechanisms in the case of noncompliance, are not covered in the following sections as they depend on high-level national and international policymaking and therefore exceed the scope of this study.

\section{Prevention mechanisms: results}

Having identified specific crime opportunities, we now want to see whether and to what extent $\mathrm{SCP}$ can provide proper guidance to mitigate these problems. From our analysis, the following SCP techniques and mechanisms (see Appendix A for the complete list) could be particularly useful to guide stakeholders and policy-makers in order to mitigate wild plant trafficking.

Traditional "increase the effort" SCP mechanisms such as target hardening (e.g. packaging requirements in case of re-export), control access to facilities (e.g. systematic baggage screening) and screen exit (e.g. forgery-proof documents) could certainly help mitigate problems linked to loopholes in the paper trails in cases of re-export and forged documents. For instance, a specific target hardening mechanism suggested by Respondent $\mathrm{A}$ is the implementation of additional documentation (at least on a voluntary basis) of material imported under Annotation 4b ("seedling or tissue cultures obtained in vitro, in solid or liquid media, transported in sterile containers”), or plants resulting from such imports. Improved 
customs procedures could help. Unfortunately, as noted by Respondent A, these types of solutions would be unrealistic unless countries are more open towards giving each other access to customs databases.

Similarly, "increase the risk" mechanisms such as reducing anonymity (e.g. use of plant IDs), utilising place managers (e.g. reward vigilance by legitimate plant dealers), and strengthening formal surveillance (e.g. more and better trained customs control officers) could play an important role. For instance, Respondent D recognised the importance of capacity-building programmes for Scientific Authorities and law enforcement bodies (especially customs officials). According to Respondent K, "it is [also] necessary to increase control activities, also at local level to give a clear signal of punishment". Respondent B stressed the need to have better training on the CITES framework for law enforcement agencies, and access to a CITES expert list to rely on whenever needed. Respondent A recommended marking individual plants in a similar way to that in place for individual animals, but the respondent also recognised that "there are difficulties to solve before this is viable". Respondent G suggested the need to finance research to generate intelligence on the main traded species, to better focus law enforcement attention.

Also "reduce the rewards" mechanisms could provide guidance for effective intervention. Specifically, "disrupt markets" is helpful in stressing the importance of monitoring online ads and sales, especially given that Internet trade appears to be frequently overlooked by law enforcement agencies (Hinsley et al. 2016); "identify properties" suggests efforts should be made to systematically record trade data for both listed and non-listed species at regional/ national levels. Otherwise, Scientific Authorities have no access to information on individual plants before export, making it difficult to determine whether they are of artificially propagated or wild origin (as suggested by Respondent E). "Deny benefits" is a useful reminder that in countries with high levels of corruption, specific policies need to be put in place to mitigate illegal trades of endangered plants. For instance, as reported by Respondent E:

"Plant species suffer of attention deficit from politicians and rulers because of low market value (except rosewood, palisander and ebony for which an anti-corruption criminal chain was established). The challenge is to extend this chain to any natural resources crime. [...] It is necessary to build capacities of customs on specimen ID but that is not enough if not supported by national effort to curb corruption within administration officers".

However, to properly implement all the above-mentioned approaches might involve significant additional resources, which are likely to clash with financial constraints. Hence, from a practical perspective, other SCP mechanisms might be more promising in tackling wild plants trafficking as they would require more limited resources.

Of particular interest are "remove excuse" mechanisms, such as "set rules" (e.g. as suggested by Respondent A, putting in place stricter guidelines for purpose codes to change; ensure proper implementation of national laws; as suggested by Respondent K, agreeing on internationally approved standards and interpretation in CITES application, e.g. in parts that are exempted by CITES provisions), "post instructions" and "alert conscience" (e.g. to display reminders of CITES requirements on airports, to flag up a CITES advert whenever someone looks to be buying a threatened species online, to request signatures for custom declarations for tourists travelling from at-risk exporting countries), and "assist compliance" (e.g. ensuring easy access to information for legal exports, for instance through travel agencies for tourists travelling towards at-risk exporting countries or on websites dedicated to horticulture; having 
adequate schemes to register nurseries at the national level). Vaglica et al. (2017), for instance, recently identified a potential way in which shoppers online could be notified if it was predicted with high probability that they were likely to want to shop for species requiring CITES controls. As suggested by Respondent E, these approaches would also develop better and more open relationships with legitimate traders, which would be very important as those are the ones with "dense network [of relationships] with botanists and plant lovers over the world and [have] premium information on [at-risk] species".

Finally, "provide opportunities" mechanisms (to facilitate compliance with CITES) are also promising. In order to tackle wild plant trafficking, they can translate into improving awareness in both the offer and the demand sides, in both the local communities harvesting endangered plants and end-buyers ("it's necessary to inform more collectors on their responsibility and increase the sensibility of people on conservation problems", Respondent K). Local communities should be made more aware of the problems connected with wild plants being smuggled illegally (Respondent $\mathrm{H}$ ), but in order for this to work alternative profitmaking opportunities need to be offered ("offer alternatives" technique). Some countries are already trying to move in this direction, which can be considered a best practice to be implemented elsewhere. Consider for instance the following answer provided by Respondent G:

\footnotetext{
"We need to establish practical alternatives for communities that depend on CITES species. To put a concrete example, all timber harvest of Dalbergia is from the wild, and [Country G] should be paving the way towards the establishment of commercial plantations (that include in their management plan, in situ conservation activities of the wild populations). We are currently working on this, in close collaboration with the local communities that will benefit from these responsible and sustainable practices (including agroforestal schemes, specifically with coffee plantations)".
}

At the same time, buyers should be made more aware and responsible, especially regarding endangered plants (such as cacti and orchids) which are illegally traded for private collectors, as well as for food and medicine.

Last but not least, to facilitate compliance with CITES more effective international cooperation is essential. Respondent $\mathrm{D}$, for instance, noted the importance on maintaining institutional coordination and good communication with other CITES Parties. However, cooperation for certain countries can be jeopardised not only by the lack of political and institutional will, but also by more mundane issues. Respondent I (from a country heavily affected by illegal trade, to the point that he/she stressed how in his/her country is becoming increasingly difficult to see critical species — such as the orchid Paphiopedilum - in the wild) emphasised how "the CITES platform [works] mainly for native English speaker and big countries. The language is a major barrier for other country[ies] [to] participate". This type of practical obstacle to international cooperation necessitates addressing an open cross-border dialogue as a matter of priority.

\section{Prevention mechanisms: discussion}

Here we have demonstrated the utility of the SCP framework as an analytical method for mapping and devising effective interventions. The SCP framework has been continually refined and extended since its inception (Newman and Freilich 2012), originally being mainly applied to more conventional, high-volume crimes (such as burglary). Our results extend the 
development of the SCP, showing how a situational approach could be particularly beneficial in a domain — such as the one in wildlife crimes, and specifically wildlife trafficking characterised by scarce and poorly resourced policing (Nurse 2011; CITES 2016; Runhovde 2016). In fact, SCP can provide a wide array of potential solutions to draw from, depending on economic (or even political) feasibility.

Second, it should be noted that, while many of the SCP mechanisms presented above have been thought specifically to mitigate and prevent the illegal trade in endangered plants, they might also provide a guide for other types of wildlife crimes in which comparable modus operandi are in place (e.g. wild animal trafficking). Furthermore, these mechanisms could have a positive spillover effect - or "diffusion of benefits", in the SCP jargon (Clarke and Weisburd 1994) — towards the prevention of other criminal activities: for instance, better mechanisms to monitor online ads and sales could help prevent online frauds; improving access by tourists to information for legal exports could help prevent some illegal trade in cultural artefacts; increasing plant collectors' awareness could help prevent illegal harvesting. Respondent E reported cases of buyers requiring specimens with particular features and sizes that can be found only from the wild, a behaviour that promotes illegal harvesting (beyond trafficking).

Finally, our success in applying the SCP framework to international plant trafficking suggests similar gains may be made by applying the framework to other conservation legislation. Other national or international species or habitat protection legislation would be natural targets, such as the common fisheries policy.

\section{Conclusion}

This study brought together criminological and conservation science expertise to systematically identify vulnerabilities in the legal framework of CITES and its implementation. It suggested and discussed potential strategies in order to prevent and mitigate the problem.

Despite the limits and critical points raised in this paper, CITES remains the most powerful international convention on biodiversity conservation. The possibility to monitor trade in endangered species and impose automatic sanctions to the non-complying parties creates a powerful tool to prevent or at least mitigate illegal trade in endangered species. Allowing the CITES Secretariat to evaluate how Parties' legislations permit the implementation of the Convention (Morgera et al. 2014), recommending the suspension of trade in CITES species for those not complying with adequate legislation, further enhances the strength of CITES.

As recognised in the latest UNODC report (2016: 96), "legislation can go some way toward enhancing the profile of wildlife crime, but law enforcement prioritization is the decisive factor". Unfortunately, the enhancement of law enforcement operational capacity requires resources that might not always be on the table for CITES Parties in source, transit and destination countries. If scarce resources have to be effectively allocated, a crime opportunity approach and SCP framework prove to be good reasoning tools to map problems and discuss potential solutions.

For instance, extra resources could be channelled towards the monitoring of online markets, ad-hoc training, and to develop forgery-proof documents. Further research to identify crime clusters in online and offline markets — "hot products", "hotspots", "risky facilities" etc. in the crime opportunity lexicon (Farrell 2015) - would certainly be of great utility in better allocating resources. The importance of independent scientific research on CITES-related 
issues and priorities has also been underlined in the European Regional CITES Plants Meeting (2014). Similarly, progress in chemical and forensic tools can help to develop cost-effective techniques to identify specific species and help enforcement of listings. For instance, as reported by RBG Kew (2016: 66), a chemical compound (“dalnigrin”) unique to Brazilian rosewood (Dalbergia nigra) was recently discovered; it has great potential as an identification tool to determine illegal trade in this specific timber.

Potential non-law enforcement/forensics based (and possibly "cheaper") solutions also emerge from our analysis. The fact that educating tourists and locals on the importance of wildlife resources may slow down the volume of illegal trade has long been advocated for wild animals (Meyers and Seligsohn Bennet 1989:106). These efforts need to be extended to protect wild plants. While it can be difficult to change cultural factors, situational techniques could start to make a difference: "post instructions" and "alert conscience" mechanisms can be particularly easy to implement and might be particularly valuable in addressing the maze of online trade. In fact, traditional law enforcement does not translate well to cyberspace (Wall 2007), so that self-help and education become the first line of defence against online crimes (Brenner 2007).

\section{Appendix}

Table 1 Techniques and mechanisms of situational crime prevention

\begin{tabular}{|c|c|c|c|c|c|}
\hline $\begin{array}{l}\text { Increase the } \\
\text { effort }\end{array}$ & Increase the risk & $\begin{array}{l}\text { Reduce the } \\
\text { rewards }\end{array}$ & $\begin{array}{l}\text { Reduce } \\
\text { provocations }\end{array}$ & Remove excuses & $\begin{array}{l}\text { Provide } \\
\text { opportunities }\end{array}$ \\
\hline Target harden & Extend guardianship & $\begin{array}{r}\text { Conceal } \\
\text { targets }\end{array}$ & $\begin{array}{l}\text { Reduce frustration } \\
\text { and stress }\end{array}$ & Set rules & Facilitate \\
\hline $\begin{array}{l}\text { Control access to } \\
\text { facilities }\end{array}$ & $\begin{array}{l}\text { Assist natural } \\
\text { surveillance }\end{array}$ & $\begin{array}{l}\text { Remove } \\
\text { targets }\end{array}$ & Avoid disputes & Post instructions & Forgive \\
\hline Screen exits & Reduce anonymity & $\begin{array}{l}\text { Identify } \\
\text { properties }\end{array}$ & $\begin{array}{l}\text { Reduce emotional } \\
\text { arousal }\end{array}$ & Alert conscience & $\begin{array}{l}\text { Offer } \\
\text { alternatives }\end{array}$ \\
\hline Deflect offenders & $\begin{array}{c}\text { Utilise place } \\
\text { managers }\end{array}$ & $\begin{array}{l}\text { Disrupt } \\
\text { markets }\end{array}$ & $\begin{array}{l}\text { Neutralise } \\
\text { peer-pressure }\end{array}$ & $\begin{array}{l}\text { Assist } \\
\text { compliance }\end{array}$ & Subsidise \\
\hline Control tools & $\begin{array}{l}\text { Strengthen formal } \\
\text { surveillance }\end{array}$ & $\begin{array}{l}\text { Deny } \\
\text { benefits }\end{array}$ & $\begin{array}{r}\text { Discourage } \\
\text { imitation }\end{array}$ & $\begin{array}{l}\text { Control drugs } \\
\text { and alcohol }\end{array}$ & Legalise \\
\hline
\end{tabular}

Open Access This article is distributed under the terms of the Creative Commons Attribution 4.0 International License (http://creativecommons.org/licenses/by/4.0/), which permits unrestricted use, distribution, and reproduction in any medium, provided you give appropriate credit to the original author(s) and the source, provide a link to the Creative Commons license, and indicate if changes were made.

\section{References}

Alacs, E., Georges, A., FitzSimmons, A., \& Robertson, J. (2010). DNA detective: a review of molecular approaches to wildlife forensics. Forensic Science, Medicine and Pathology, 6(3), 180-194.

Albrecht, H. J., \& Kilching, M. (2002). Crime risk assessment, legislation, and the prevention of serious crime. Comparative perspectives. European Journal of Crime, Criminal Law and Criminal Justice, 10(1), 25-38.

Bowman, M. (2013). A tale of two CITES: divergent perspectives upon the effectiveness of the wildlife trade convention. Review of European, Comparative and International Environmental Law, 22(3), 228-238. 
Brenner, S. W. (2007). Cybercrime: Re-thinking crime control strategies. In Y. Jewkes (Ed.), Crime Online (pp. 12-28). Portland: Willan.

CITES (2016). Wildlife Crime. What are the challenges to effective law enforcement? Available at: https://cites. org/prog/iccwc.php/Wildlife-Crime.

Clarke, R. V. (1992). Situational crime prevention. Successful case studies. New York: Harrow and Heston.

Clarke, R. V. (2009). Situational Crime Prevention. In R. Wortley \& L. Mazerolle (Eds.), Environmental criminology and crime analysis. Devon: Willan.

Clarke, R.V. (2012). Opportunity makes the thief. Really? And so what? Crime Science, 1(2). doi:10.1186/21937680-1-3.

Clarke, R. V., \& Weisburd, D. (1994). Diffusion of crime control benefits: observation on the reverse displacement. Crime Prevention Studies, 2, 165-183.

CoP 17 (2016). Seventeenth meeting of the CITES Conference of the Parties, Johannesburg, 24 September-04 October 2016. Available at: https://cites.org/eng/cop/index.php.

Cornish D. B. and Clarke R. V. (2003). “Opportunities, precipitators and criminal decisions: A reply to Wortley’s critique of situational crime prevention". In M. J. Smith and D. B. Cornish (Eds.), Crime prevention studies no. 16. New York: Criminal Justice Press.

Couzens, E. (2013). CITES at forty: never too late to make lifestyle changes. Review of European, Comparative \& International Environmental Law, 22(2), 311-323.

Dobson, A. P. (1996). Conservation and biodiversity. Princeton University Press, Princeton

Dorn, N., Van Daele, S., \& Vander Beken, T. (2007). Reducing vulnerabilities to crime of the European waste management industry: the research base and the prospects for policy. European Journal of Crime, Criminal Law and Criminal Justice., 15(1), 23-36.

EIA (2016). The Hongmu Challenge. A briefing for the 66th meeting of the CITES Standing Committee, January 2016. Environmental Investigation Agency. Available at: https:/eia-international.org/report/the-hongmuchallenge.

Engler, M. \& Parry-Jones, R. (2007). Opportunity or threat. The role of the European Union in global wildlife trade. Report, Brussels: TRAFFIC Europe.

European Regional CITES Plants Meeting (2014). Recommendations. IX European Regional CITES Plants Meeting, Wageningen, The Netherlands 11-14 November 2014.

Farrell, G. (2015). Crime concentration theory. Crime Prevention and Community Safety, 17(4), 233-248.

Felson, M. \& Clarke, R.V. (1998). Opportunity makes the thief: practical theory for crime prevention. Police research series, paper no. 98. London: Home Office.

Freilich, J. D., \& Newman, G. R. (2014). Providing opportunities: A sixth column for the techniques of situational crime prevention. In S. Caneppele \& F. Calderoni (Eds.), Organised crime, corruption and crime prevention. London: Springer.

Gibbs, C., Gore, M. L., McGarrell, E. F., \& Rivers, L. (2010). Introducing conservation criminology. Towards interdisciplinary scholarship on environmental crimes and risks. The British Journal of Criminology, 50(1), 124-144.

Gillespie, A. (2011). Conservation, biodiversity and environmental law. Cheltenham: Edward Elgar.

Haenlein, C., \& Smith, M. L. R. (2017). Poaching, wildlife trafficking and security in Africa: Myths and realities. London: RUSI.

Herbig, F. J. W., \& Joubert, S. J. (2006). Criminological semantics. Conservation criminology - vision or vagary? Acta Criminologica, 19(3), 88-103.

Hinsley, A., Nuno, A., Ridout, M., St John, F. A. V., \& Roberts, D. L. (2016). Estimating the extent of CITES noncompliance among traders and end-consumers; lessons from the global orchid trade. Conservation Letters. doi:10.1111/conl.12316.

Interpol. (2013). Project web. An investigation into the ivory trade over the internet within the European Union. Lyon: Interpol.

Izzo, J.B. (2010). PC pets for a price: combating online and traditional wildlife crime through international harmonisation and authoritative policies. William \& Mary Environmental Law and Policy Review, 34(3), 965.

Kew, R. B. G. (2016). State of the World's plants. Kew: Royal Botanic Gardens.

Lavorgna, A. (2014). Wildlife trafficking in the internet age. Crime Science, 3(5), 1-12.

Lemieux, A. M. (2014). Situational prevention of poaching. Abingdon, Oxon: Routledge.

Lemieux, A. M. (2015). Geotagged photos: a useful tool for criminological research? Crime Science, 4, 3.

Lemieux, A. M., \& Clarke, R. V. (2009). The international ban on ivory sales and its effects on elephant poaching in Africa. British Journal of Criminology, 49(4), 451-471.

Maher, J., \& Sollund, R. (2016). Law enforcement of wildlife trafficking: a comparative strengths, weaknesses, opportunities and threats analysis of the UK and Norway. Journal of Trafficking, Organized Crime and Security, 2(1), 82-99. 
McCoyd, J. L. M., \& Kerson, T. S. (2006). Conducting intensive interviews using emails. Qualitative Social Work, 5(3), 389-406.

McGough, H.N., Groves, M., Mustard, M., Brodie, M. (2004). CITES and plants: A user's guide version 3.0. Kew: Royal Botanic Gardens.

Meyers, G. D., \& Seligsohn Bennett, K. (1989). Answering "the call of the wild": an examination of US participation in international wildlife law. Pace Environmental Law Review, 7, 75

Moreto, V. D. (2016). Introduction to special issue. Trends in Organised Crime, 19(1), 1-3.

Moreto, W. D., \& Clarke, R. V. (2013). Script analysis of the transnational illegal market in endangered species. Dream and reality. In B. Lecrec \& R. Wortley (Eds.), Cognition and crime: Offender decision-making and script analysis. London: Routledge.

Morgan, R., \& Clarke, R. V. (2006). Legislation and unintended consequences for crime. The European Journal on Criminal Policy and Research, 12, 189-211.

Morgera, E., Tsioumani, E. \&, Matthias, B. (2014). Unravelling the Nagoya Protocol. A Commentary on the Nagoya Protocol on Access and Benefit-sharing to the Convention on Biological Diversity. Legal Studies on Access and Benefit-sharing. Vol. 2. Leiden: Koninklijke Brill nv.

Newman G .R. and Freilich J. D. (2012). "Extending the reach of situational crime prevention". In N. Tilley and G. Farrell (Eds.), The reasoning criminologist. Essays in honour of Ronald V. Clarke. Oxon: Routledge.

Nurse, A. (2011). Policing wildlife: perspectives on criminality in wildlife crime. The British Criminology Conference, 11, 38-53.

O’Connor, H., \& Madge, C. (2017). Online interviewing. In N. G. Fielding, R. M. Lee, \& G. Blank (Eds.), The SAGE handbook of online research methods. London: SAGE.

Olmos-Lau, V. R., \& Mandujano, M. C. (2016). An open door for illegal trade: online sale of strombocactus disciformis (cactacae). Nature Conservation, 15, 1-9.

Phelps, J., \& Webb, E. L. (2015). "Invisible" wildlife trades: Southeast Asia's undocumented illegal trade in wild ornamental plants. Biological Conservation, 186, 296-305.

RBG Kew. (2017). State of the World's plants. Kew: Royal Botanic Gardens.

Regan, K. E. (2004). The need for a comprehensive approach to protecting rare plants: Florida as a case study. Natural Resources Journal, 44(1), 125-162.

Rivalan, P., Delmas, V., Angulo, E., Bull, L. S., Hall, R. J., Courchamp, F., Rosser, A. M., \& Leader-Williams, N. (2007). Can bans stimulate wildlife trade? Nature, 447, 529-530.

Runhovde, S.R. (2016). Taking the path of least resistance? Decision-making in police investigations of illegal wildlife trade. Policing: A Journal of Policy and Practice. doi:10.1057/9781137456267_8.

Russell, M., \& Clarke, R. V. (2006). Legislation and unintended consequences for crime. European Journal of Criminal Policy and Research, 12, 189-2011.

Sajeva, M., \& Carimi, F. (1994). Il ruolo della micropropagazione nella conservazione di piante succulente minacciate di estinzione per la loro importanza economica. Quaderni Bot Ambientale App, 5, 55-60.

Sajeva, M., Carimi, F., \& McGough, N. (2007). The convention on international trade in endangered species of wild Fauna and Flora (CITES) and its role in conservation. Functional Ecosystems and Communities, 1, 80-85.

Sajeva, M., McGough, H. N., Garrett, L., Luthy, J., Tse-Laurence, M., Rutherford, C., \& Sajeva, G. (2012). CITES and cacti: A user's guide. Kew: Royal Botanic Gardens.

Sand, P. H. (1997). Whither CITES? The evolution of a treaty regime in the borderland of trade and environment. European Journal of International Law, 8(1), 29-58.

Sand, P. H. (2013). Enforcing CITES: the rise and fall of trade sanctions. Review of European, Comparative \& International Environmental Law, 22(3), 251-263.

Savona, E.U. (2017). Proofing legislation against crime as situational prevention measure. In B. LeClerc \& E.U. Savona (Eds.) Crime prevention in the 21st century, (pp. 247-274). doi:10.1007/978-3-319-27793-6_16.

Sollund, R. (2011). Expressions of speciesism: the effect of keeping companion animals on animal abuse, animal trafficking and species decline. Crime, Law and Social Change, 55(5), 437-451.

Sollund, R. (2015). Green harms and crimes. Critical criminology in a changing world. London: Palgrave.

Sollund, R. \& Maher, J. (2015). Illegal wildlife trade. A case study on illegal wildlife trade in the United Kingdom, Norway, Colombia and Brazil. Report produced as part of EFFACE. Available at: http://efface. eu/illegal-wildlife-trade-case-study-report-illegal-wildlife-trade-united-kingdom-norway-colombiaandoverlay-context=case-studies

Transcrime (2006). A study on crime proofing - Evaluation of crime risk implications of the European Commission's proposal covering a range of policy areas. Available at: http://www.transcrime.it/wpcontent/uploads/2013/11/Final_Manual-A_study_on_Crime_Proofing.pdf.

UNODC. (2016). World wildlife crime report. Trafficking in protected species. Vienna: UNOCD.

Vaglica, V. (2016). An ITTO fellow makes the case for listing the entire Dalbergia genus in CITES appendix II. ITTO Tropical Forest Update, 25(1), 24-26. 
Vaglica, V., Sajeva, M., McGough, H. N., Hutchison, D., Russo, C., Gordon, A. D., Vonjy Ramarosandratana, A., Stuppy, W., \& Smith, M. J. (2017). Monitoring internet trade to inform species conservation actions. Endangered Species Research, 32, 223-235.

van Solinge, T. B. (2008). Eco-crime: The tropical timber trade. In D. Siegel \& H. Nelen (Eds.), Organized crime: Culture, market and policies. New York: Springer.

Vézina, P. L. (2015). Illegal trade in natural resources: evidence from missing exports. International Economics, $142,152-160$.

Wall, D. S. (2007). Cybercrime: The transformation of crime in the information age. Cambridge: Polity.

Warchol, G. L. (2004). The international illegal wildlife trafficking. Criminal Justice Studies: a Journal of Crime, Law and Society, 17(1), 57-73.

Wellsmith, M. (2010). The applicability of crime prevention to problems of environmental harm: A consideration of illicit trade in endangered species. In R. D. White (Ed.), Global environmental harm: Criminological perspectives. Devon: Willan.

Wortley, R. (1997). Reconsidering the role of opportunity in situational crime prevention. In G. R. Newman, R. V. Clarke, \& S. G. Shoham (Eds.), Rational choice and situational crime prevention. Dartmouth: Ashgate.

Wu, J. (2007). World without borders: wildlife trade on the Chinese-language internet. TRAFFIC Bulletin, 21(2), 75-84.

Wyatt, T. (2013). Wildlife trafficking: A deconstruction of the crime, the victims and the offenders. Basingstoke: Palgrave Macmillan.

Wyatt, T. (2014). The Russian far East's illegal timber trade: an organized crime? Crime Law and Social Change, $61(1), 15-35$.

Wyatt, T. (2016). A comparative analysis of wildlife trafficking in Australia, New Zealand and the United Kingdom. Trafficking, Organised Crime and Security, 2(1), 62-81.

Young, S. (2003). Contemporary issues of the convention on international trade in endangered species of wild Fauna and Flora (CITES) and the debate over sustainable use. Journal of international Environmental Law and Policy, 14(1), 167-189.

Zimmerman, M. E. (2003). The black market for wildlife: combating transnational organized crime in the illegal wildlife trade. Vanderbilt Journal of Transnational Law, 36, 1657-1689. 